\title{
One Stone, Two Birds: Maximizing Service Learning Outcomes through TESOL Practicum
}

\author{
Ping Yang ${ }^{1}$ \\ ${ }^{1}$ School of Humanities and Communication Arts, University of Western Sydney, Australia \\ Correspondence: Ping Yang, School of Humanities and Communication Arts, University of Western Sydney, \\ Locked Bag 1797, Penrith, NSW 2751, Australia. Tel: 61-2-9772-6514. E-mail: p.yang@uws.edu.au
}

Received: November 11, 2013 Accepted: February 21, 2014 Online Published: April 14, 2014

doi:10.5539/elt.v7n5p120 URL: http://dx.doi.org/10.5539/elt.v7n5p120

\begin{abstract}
This paper examines a good practice for service learning that has been implemented for years in TESOL Internship, a professional unit for students doing Master of Arts (MA) in Teaching English to Speakers of Other Languages (TESOL) at a major university in Australia. The author has investigated and identified three key features of a good practice in service learning, including critical reflection, community engagement and intercultural communication, which are evidenced in student service learning in various English language centres in Great Western Sydney. Data are collected from student reports, supervising teachers' reports and comments, weekly workshop discussions and emails. Using constructivist grounded theory (Glaser \& Strauss, 1967), the author conducts thematic analysis to code the data, categorizes them into key themes for critical analysis. The results show that during their practicum period TESOL student teachers critically reflect on their observation experience and participate in curriculum-relevant and extra-curriculum activities, particularly their own teaching practices drawing on relevant TESOL theories and communicating with their peers and mentors. Furthermore they come to understand local communities better as they are actively engaged in interacting with members of local communities. Finally their intercultural awareness is enhanced through regular and active intercultural communication with people of diverse language and cultural backgrounds. Opportunities and challenges for good service learning practices are also discussed.
\end{abstract}

Keywords: service learning, TESOL practicum, critical reflection, community engagement, intercultural learning

\section{Introduction}

Along with emphasis on teaching quality and research outcomes, more and more international universities have focused on students' critical analysis, community engagement and intercultural awareness. For example, University of Western Sydney (UWS) promotes community engagement, which "provides a focal point for activities involving the community and creates opportunities for development of relationships and interaction with external and internal partners" (UWS Engagemennt, 2014). Such active engagement with diverse communities can take place at local, national and international level and take various forms such as "joint research projects, engaged learning opportunities and community engagement activities" (UWS Engagemennt, 2014). Service learning, one of the three practicum components in TESOL Internship program at UWS, provides an opportunity for interns to actively participate in various engaged learning tasks and interact with members of diverse communities, and further enables them to communicate with their mentors for professional development on a mutually beneficial basis (Smolen, Zhang, \& Detwiler, 2013; Yang, 2013). It is generally acknowledged that building connections and maintaining relationships between university coursework and diverse communities will benefit both university students and community members.

This project examines a good practice for service learning that has been implemented for years in TESOL Internship, a professional unit taken by students doing MA in TESOL at UWS. The author has investigated and identified three key features of a good practice in service learning, including critical analysis and reflection, community engagement and intercultural awareness. These service learning activities enable interns to put TESOL theories (e.g. teaching methodology and curriculum development) into practice, forge fundamental part of TESOL teacher education and benefit their ongoing professional development and future career.

The author will first briefly review the current literature in service learning concerning the three key features 
identified, and then describe research method used and procedures for data analysis. The discussion highlights the fact that UWS TESOL interns have made achievements in their service learning through undertaking critical reflection, community engagement and intercultural learning at various practicum locations. Furthermore, challenges and opportunities arising from service learning are discussed and recommendations are made to maximize TESOL student in-context service learning experience.

\section{Theoretical Consideration}

Service learning is characterized by its unique channel through which students engage themselves in a range of participation-reflection-learning activities outside of traditional classroom environment. It is considered by Bringle and Hatcher (1995, p. 112) as "a course-based, credit-bearing educational experience in which students (a) participate in an organized service activity that meets identified community needs and (b) reflect on the service activity in such a way as to gain further understanding of course content, a broader appreciation of the discipline, and an enhanced sense of civic responsibility". Such uniqueness enables student teachers to become motivated to participate in various planned social activities with definite objectives, reflecting on real-life events and authentic experiences that connect with their future careers, and learning to put theories into practice in different work placement settings. The literature review focuses on current work on service learning with reference to critical reflection, community engagement and intercultural communication.

Skills in critical analysis and reflection are important for adult learners. While engaged in service learning in the workplace, the interns plan relevant activities, aim to complete them, and reflect on what they do. Three methods are used. First, they keep a journal recording details of what, where and why things happen, writing down their personal observations, experience and reflection (Crookes, 2003; Kahl, 2010), focusing on finding gaps between TESOL theories and classroom practices, engaging in group discussion and working on effective measures to bridge them. Second, interns undertake learning needs analysis of their students, assist small student groups and provide individual literacy support. Such experience enables them to critically reflect on their own learning experience and its impact on the students' academic achievements (Hart \& King, 2007; Roschelle, Turpin, \& Elis, 2000). With this in mind, interns think more carefully and deeply of using flexible teaching methods, accommodating their students' learning needs and working to make their learning experience better. Third, interns are invited to give individual presentation as reflection and share experience with their peers (Littlefield, 2006). Throughout their service learning period, students critically analyse their personal learning experience, through "participatory writing" (Dubinsky, 2006), and meet community language literacy needs and social change.

One of the most meaningful service learning activities which interns participate in is to engage with diverse communities, building and maintaining collaborative relationship (Dempsey, 2010), including multicultural service learning (Chang, Anagnostopoulos, \& Omae, 2011), collaborative community service (Crossman \& Kite, 2007), multiculturalism (Fitzgerald, 2009). It's very important to establish and maintain community-university partnership (Curwood, Farrar, Mackeigan, Mitchell, \& Munger, 2011; Lambert-Pennington, Reardon, \& Robinson, 2011) as such connection will benefit both parties and bring them together. Community members (e.g. parents, high school students and alumni) are informed and invited to attend various events (e.g. availability of sports and gym facilities, Open Days, public lectures and movies) that are scheduled on the university campuses. Their personal experience with the campus life and individual interaction with university staff members help them understand the diverse university life and appreciate the important role of higher education. Many of them show interest in doing university coursework or research degree to enhance their employment opportunities or get a better job. Amey, Eddy, and Campbell (2010) examine how effective and collaborative community college partnership could help achieve maximum economic outcomes. University staff members can have their patents and inventions commercialised and, at the same time, serve communities and businesses. Various community organizations provide funding and maintain partnership to support university-based teaching activities and research projects. In a word, interns actively participating in service learning with a purpose tend to develop a stronger sense of community service and engagement, and intercultural awareness.

TESOL interns increase and enhance their intercultural learning experience during service learning period when they interact with people including students, colleagues and community members from different linguistic and cultural backgrounds (Yang, 2013). Such experience helps them understand various linguistic and cultural differences (e.g. language variations, accents, diverse cultural practices and values) in many communities. This enhances mutual intercultural understanding (Dull, 2009), enables all parties to appreciate cultural diversity (Mitton-Kükner, Nelson, \& Desrochers, 2010) and strengthen intercultural awareness while engaged in intercultural interaction. African refugees relocating to the United States experience communication and cross-cultural challenges, particularly feeling socially rejected and isolated, and emotionally negative, along with 
positive experience (Semlak, Pearson, Amundson, \& Kudak, 2008). TESOL interns interact with the recently arrived refugees and provide language assistance to meet their learning needs, help improve their communication skills that are needed for their employment opportunities and socialization. However, ESL teachers and interns need to well prepare for language teaching and learning challenges they face while working with this special group of learners in transitional status (Wachob \& Williams, 2010).

\section{Procedures}

In the past few years, UWS TESOL Internship has been working closely with a number of English language colleges and centres in Greater Western Sydney, where nationally accredited English Language Intensive Courses for Overseas Students (ELICOS) (National ELT Accreditation Scheme, 2014) in English for Academic Purposes (EAP) program, Adult Migrant English Program (AMEP (Note 1)) and Skills for Education and Employment (SEE (Note 2)) are offered. EAP program is designed and taught to international students who wish to improve their English skills to gain entry into an Australian university for further studies. AMEP is developed and offered to the recently arrived immigrants and refugees, who want to gain functional English communication (spoken and written) skills for employment and socialization purposes. SEE program provides practical and effective skills, particularly literacy and/or numeracy, needed by a range of job seekers to join Australian labor force and they come from different ethnic groups, including Aboriginal and Torres Strait Islanders, youth, people with disabilities, mature aged people and job seekers of diverse linguistic and cultural backgrounds. The TESOL interns undertake engaged practicum, including class observation, service learning and supervised teaching, in one of the English language centres where either EAP, AMEP and/or SEE programs are delivered. They are also encouraged to undertake additional hours of engagement in tutoring various groups of language learners on a volunteer basis (Note 3).

This research project uses constructivist grounded theory (Glaser \& Strauss, 1967) which focuses on the information emerging from the data collected from the real-life situation, rather than having "preconceived ideas to prove or disprove" (Stoller, 1999, p. 2). The data sources include a large variety of documents, such as student reports, teacher mentor reports, internship journals, email communication with the internship students, supervising teachers and education coordinators. The data are thematically categorised and analysed. The results are summarised and discussed in the following section.

\section{Getting Most Out of Service Learning Activities}

While general service learning can include a wide range of learning activities, UWS TESOL student service learning focuses on two broad areas, curriculum-related and extra-curriculum relevant learning activities (Yang, 2013). Curriculum-related service learning activities include examining TESOL curriculum materials such as commercially available textbooks and teacher-designed and developed resources, planning lesson plans, coaching individual students who need learning assistance, and assisting the teacher, for example, in administering a placement test to the new arrivals in order to match them to an appropriate class level. Extra-curriculum relevant learning activities cover attending professional and workplace-related training sessions (e.g. computer skills and Occupation, Health \& Safety) and staff meetings, participating in student activities (student excursions, speech competition, mini sports meet) and assisting in supervising student group activities.

The three key features of UWS TESOL student service learning experiences are summarized and discussed in the following sections with reference to the above-mentioned documents and data collected.

\subsection{Critical Reflection}

One of the important skills UWS TESOL interns have developed while undertaking their service learning activities in an English centre is that they engage themselves in critically analysing their participation and reflecting on their experiences. Similar pros about service learning experience and results are discussed by Lally (2001). One TESOL student teacher noted that while he participated in curriculum-related service learning activities (e.g. examining curriculum resources), he was aware of the need to use culture-inclusive teaching and learning materials so that his students with diverse cultural backgrounds had exposure to other cultural events and knowledge. Such awareness found him preparing some interesting pictures and photos relevant to the content topics and language skills, using both commercial textbooks and teacher-developed materials. After each teaching session, he reflected on the teaching and learning activities in which using pictures and photos facilitated student learning, promoted cultural diversity and helped achieve teaching outcomes. Furthermore, after consulting his teacher mentor, he was thinking of using videos (P. Ambard \& L. Ambard, 2012) and Internet resources (Blake, 2009) as supplementary and alternative means to enhancing teaching and learning purposes. Meanwhile they checked all materials to be used and ensured that they were inclusive but not 
offensive to any culture.

Another point of critical reflection valued by the interns centres around putting TESOL theories into guided practice more thoughtfully in specific pedagogical contexts rather than using one-size-fits-all approach. However, this does not reject their taking adventure or prevent them from experimenting their methods. They can, in fact, add to their experience and motivate them to reflect on trial and error. Emsheimer and De Silva1 (2011) think that interns will have a better chance to understand theories when they connect them with their practicum experiences. Further experiments driven by critical reflection enable interns to become inclined to explore innovation and flexibility in facilitating student learning. For example, some non-native English speaking interns insist that ESL learners may learn more effectively and increase confidence if their first language resources are selectively utilised in classroom instructions while others believe that ESL should be taught in a target language only despite Bateman's (2008) finding that factors which influence the target language use include the student teachers per se, their students, the subject matter they teach and their teacher mentors. However, an increasing number of research projects (Carless, 2008; Copland \& Neokleous, 2011; Hall \& Cook, 2012; Sparks, 2012) have demonstrated that it is sensible and wise for ESL/EFL teachers and learners to use L1 skills and resources in teaching and learning L2 in a selective and balanced manner though the context is complex and it varies with classrooms and students. This seems to work more effectively with ESL beginners in general, and those taking a translation unit, where a contrastive analysis of L1 and L2 works to present the contextual differences of lexical meaning of some words and their lexical in-equivalency in translation studies (Yang, 2011, 2012). Additionally, using L1 is particularly helpful when dealing with language terminologies and grammatical terms with which students are less familiar, thus making it possible to increase their confidence in L2 learning.

\subsection{Community Engagement}

In compliance with UWS community engagement, UWS TESOL Internship is thoughtfully planned and organized to connect student teachers with a range of community members through various English language centres in Greater Western Sydney. One of the focal points for activities engaging the community is building and maintaining partnerships between UWS TESOL Internship and various English language program providers. Such partnerships are mutually beneficial in that UWS student teachers maximize their service learning objectives and social experiences just like what has been discussed by Roschelle et al. (2000) and the communities are provided with services which aim to contribute to the development, wellbeing and prosperity of the communities (UWS Engagemennt, 2014). UWS celebrates UWS Partnership Awards winners every year to encourage the sustainable linkage with varied communities. UWS Internship's community engagement has been so successful that one of its partnership organizations TAFE International Education Centre (TIEC) in Liverpool won a UWS Partnership Award in Dec. 2011.

Interns undertaking their service learning in various partnership English centres focus on curriculum-relevant and extra-curriculum activities, thus achieving contextual learning within communities (Dodd \& Lilly, 2000). UWS interns' email communication shows while working with various community members on a daily basis, they come to understand their learning needs for functional English communication skills for employment and socialization on the one hand, and for academic English communication skills for further studies on the other. The student teachers adopt authentic teaching materials and focus on practical and meaningful communication activities, such as guiding their students in reading job selection criteria, filling application forms, and writing personal and business letters, etc. It is through these and other activities like assisting in a student trip or a speech competition that out-of-class group work helps build and maintain student-teacher rapport and easy-going interpersonal relationships. Such interactive service learning activities enable interns to gain in-context knowledge about how teaching can benefit from various service learning activities which provide valuable professional development for the mentors as well (Bell, 1999).

Apparently UWS service learning at various English language colleges and centres also benefits the placement providers in that this partnership creates an opportunity for experienced teachers to participate in mentoring student teachers, reflect on their own teaching practices, engage in team teaching and group work, and undertake professional development via in context interaction (Yang, 2013). Of course, well-progressed as service learning is, just as Delaney (2012) points out, more research needs to be done to address issues and challenges, such as expectations in mentoring relationship, interaction between speakers of different linguistic and cultural backgrounds, etc.

\subsection{Intercultural Awareness}

Although EAP, AMEP and SEE programs run at various English colleges and centres have different aims and objectives and varied learning contents, one similar feature is that the interns work with learners from diverse 
linguistic and cultural backgrounds, which provides a pedagogical setting in which UWS TESOL interns strengthen their intercultural awareness through doing a variety of service learning activities. Both curriculum-relevant and extra-curriculum service learning activities that are discussed above have seen the interns interact with AMEP learners, listening to their life stories, both sad and happy ones, sharing with them ESL learning experience. This enables them to communicate with a wide range of diverse communities, particularly those marginalized ones (Butcher et al., 2003). There is also evidence that classroom teachers' intercultural awareness helps establish cooperative working relationships and transform the learners (De Costa, 2010).

To help these disadvantaged groups settle into Australian communities and begin their new life and career in the host country, according to a few interns's journal, UWS TESOL interns volunteer with Mission Australia and participate in home tutor scheme (Note 4) and coach recently arrived migrants and refugees who may have experienced trauma or personal violence in their home countries. Thus it is important that mutual trust be fostered and more appropriate physical space, patience, assistance and time become helpful, thus building their confidence and interest in learning when the contents are authentic and related to their daily life (Finn, 2010). With intercultural understanding and sensitivity, the interns become more interested in interacting with the learners of different age and ethnic groups, getting to know their cultural values and social practices (e.g. not using left hand during interaction with Arabic speakers, avoid having physical contact with Arabic speaking females) while assisting them in learning or improving English for job purposes and everyday or workplace communication skills. Interns' reports show that they have come to develop their intercultural sensitivities and awareness, and enhance their appreciation of cultural differences and diversity (Ferfolja, 2009). It is particularly rewarding for them to view cultural differences positively, treat people equally, and take this positive experience with them to the future career.

While service learning provides TESOL interns valuable and contextual experiences, it helps them identify various challenges (Hou, 2010), particularly when they work with different communities (Petersen \& Dunbar-Krige, 2012). Basically two issues remain the biggest challenges confronting the student teachers who work with the newly arrived refugees and asylum seekers. One challenge is that some of these new immigrants are even illiterate in their first language, let alone English skills because they haven't got an opportunity to go to school before arriving in Australia. The other challenge is that some of them had traumatic experience in their home country and are not willing or find it difficult to socialize with other people and tend to either stay away or use many other coping strategies (Khawaja, White, Schweitzer, \& Greenslade, 2008). However, these challenges provide interns opportunity to work together with relevant parties (counsellors, social welfare workers and teacher mentors) to identify the needs of their students, provide individual learning assistance and support, and allow them to progress at their own pace. Difficult as it is, they don't give up, but look collectively for solutions and opportunities. To help TESOL student teachers work with the marginalised group of language learners, intercultural communication and awareness training is highly useful for them to understand and learn how to approach and interact strategically and interpersonally with them in various settings.

\section{Conclusion}

The above discussion has focused on three perspectives where UWS TESOL interns have got most out of their service learning such as undertaking critical analysis and reflections on in-context experiences, engaging in working for and serving the language learning needs of local communities and raising intercultural awareness through social interaction with people from diverse linguistic and cultural backgrounds. These initiatives have not only provided student teachers opportunities to connect with diverse community members, particularly recently arrived immigrants and refugees, and help improvements in positive behaviors and attitudes (Erickson, 2009; Farber, 2011), but also opened up a window for a wide range of people to get closer to the higher institutions and feel the power of knowledge and further education. Hence, service learning has offered mutual benefits to student teachers and community members and provided them with practical experience.

Such hands-on experience enables them to connect the service learning-based TESOL coursework with future employment, thus making their learning authentic, creative and meaningful. In this sense, opportunities arise as they continue meeting challenges and addressing issues. It has to be pointed out that this study used a limited source of data. Feedback from additional parties, such as the recently arrived immigrants and refugees, may tell their own positive experience learning English, improving language skills and getting jobs and settling into the community. It may also keep teacher researchers and interns informed of arising issues and motivate them to take further actions to help them make more progress. Although it may take time for TESOL student teachers to grasp interacultural communication skills and apply effective teaching methodology and curriculum development theories in various settings (e.g. classrooms, independent learning centres and field trips) 
supervised by qualified and experienced teacher mentors, all parties involved will find service learning educational and relevant to their individual experience and professional career.

\section{Acknowledgements}

I thank all people who provided useful information for this project.

\section{References}

Ambard, P. D., \& Ambard, L. K. (2012). Effects of narrative script advance organizer strategies used to introduce video in the foreign language classroom. Foreign Language Annals, 45(2), 203-228. http://dx.doi.org/10.1111/j.1944-9720.2012.01189.x

Amey, M. J., Eddy, P. L., \& Campbell, T. G. (2010). Crossing boundaries creating community college partnerships to promote educational transitions. Community College Review, 37(4), 333-347. http://dx.doi.org/10.1177/0091552110365725

Delaney, Y. A. (2012). Research on mentoring teachers: Its role in language education. Foreign Language Annals, 45(s1), s184-s202. http://dx.doi.org/10.1111/j.1944-9720.2011.01185.x

Bateman, B. E. (2008). Student teachers' attitudes and beliefs about using the target language in the classroom. Foreign Language Annals, 41(1), 11-28. http://dx.doi.org/10.1111/j.1944-9720.2008.tb03277.x

Bell, D. (1999). Rise, Sally, rise: Communicating through dance. TESOL Journal, 8(1), 27-31. http://dx.doi.org/10.1002/j.1949-3533.1999.tb00153.x

Blake, C. (2009). Potential of text-based Internet chats for improving oral fluency in a second language. The Modern Language Journal, 93(2), 227-240. http://dx.doi.org/10.1111/j.1540-4781.2009.00858.x

Bringle, R. G., \& Hatcher, J. A. (1995). A service-learning curriculum for faculty. Michigan Journal of Community Service Learning, 2(1), 112-122.

Butcher, J., Howard, P., Labone, E., Bailey, M., Smith, S. G., McFadden, M., .. Martinez, K. (2003). Teacher education, community service learning and student efficacy for community engagement. Asia-Pacific Journal of Teacher Education, 31(2), 109-124. http://dx.doi.org/10.1080/13598660301612

Carless, D. (2008). Student use of the mother tongue in the task-based classroom. ELT Journal, 62(4), 331-338. http://dx.doi.org/10.1093/elt/ccm090

Chang, S.-P., Anagnostopoulos, D., \& Omae, H. (2011). The multidimensionality of multicultural service learning: The variable effects of social identity, context and pedagogy on pre-service teachers' learning. Teaching and Teacher Education, 27(7), 1078-1089. http://dx.doi.org/10.1016/j.tate.2011.05.004

Copland, F., \& Neokleous, G. (2011). L1 to teach L2: Complexities and contradictions. ELT Journal, 65(3), 270-280. http://dx.doi.org/10.1093/elt/ccq047

Crookes, G. (2003). A practicum in TESOL: Professional development through teaching practice. Cambridge: Cambridge University Press.

Crossman, J. M., \& Kite, S. L. (2007). Their perspectives: ESL students' reflections on collaborative community service learning. Business Communication Quarterly, 70(2), 147-165. http://dx.doi.org/10.1177/1080569907301776

Curwood, S. E., Farrar, A., Mackeigan, M., Mitchell, T., \& Munger, F. (2011). Building effective community-university partnerships: Are universities truly ready? Michigan Journal of Community Service Learning, 17(2), 15-26.

De Costa, P. I. (2010). From refugee to transformer: A Bourdieusian take on a Hmong learner's trajectory. TESOL Quarterly, 44(3), 517-541. http://dx.doi.org/10.5054/tq.2010.226856

Dempsey, S. E. (2010). Critiquing community engagement. Management Communication Quarterly, 24(3), 359-390. http://dx.doi.org/10.1177/0893318909352247

Dodd, E. L., \& Lilly, D. H. (2000). Learning within communities: An investigation of community service-learning in teacher education. Action in Teacher Education, 22(3), 77-85. http://dx.doi.org/10.1080/01626620.2000.10463022

Dubinsky, J. (2006). The role of reflection in service learning. Business Communication Quarterly, 69(3), 306-311. http://dx.doi.org/10.1177/108056990606900308

Dull, L. J. (2009). “Some people don’t deserve help”: Service learning in Serbia. Intercultural Education, 20(1), 


\section{1-60. http://dx.doi.org/10.1080/14675980802700771}

Emsheimer, P., \& De Silva, N. L. (2011). Preservice teachers' reflections on practice in relation to theories. In M. Mattsson, T. V. Eilertsen, \& D. Rorrison (Eds.), A practicum turn in teacher education (pp. 147-167). The Netherland: Sense Publishers.

Erickson, J. A. (2009). Service-learning's impact on attitudes and behavior: A review and update. In J. R. Strait, \& M. Lima (Eds.), The future of service-learning: New solutions for sustaining and improving practice (pp. 106-118). Sterling, Virginia: Stylus Publishing.

Farber, K. (2011). Change the world with serive learning: How to organize, lead, and assess service-learning projects. New York: Rowman \& Littlefield Education.

Ferfolja, T. (2009). The Refugee Action Support Program: Developing understandings of diversity. Teaching Education, 20(4), 395-407. http://dx.doi.org/10.1080/10476210902741239

Finn, H. B. (2010). Overcoming barriers: Adult refugee trauma survivors in a learning community. TESOL Quarterly, 44(3), 586-596. http://dx.doi.org/10.5054/tq.2010.232338

Fitzgerald, C. M. (2009). Language and community: Using service learning to reconfigure the multicultural classroom. Language and Education, 23(3), 217-231. http://dx.doi.org/10.1080/09500780802510159

Glaser, B., \& Strauss, A. (1967). The discovery of grounded theory: Strategies for qualitative research. Chicago: Aldine.

Hall, G., \& Cook, G. (2012). Own-language use in language teaching and learning. Language Teaching, 45(3), 271-308. http://dx.doi.org/10.1017/S0261444812000067

Hart, S. M., \& King, J. R. (2007). Service learning and literacy tutoring: Academic impact on pre-service teachers. Teaching and Teacher Education, 23(4), 323-338. http://dx.doi.org/10.1016/j.tate.2006.12.004

Hou, S.-I. (2010). Developing a faculty inventory measuring perceived service-learning benefits and barriers. Michigan Journal of Community Service Learning, 16(2), 78-89.

Kahl, D. H. (2010). Connecting autoethnography with service learning: A critical communication pedagogical approach. Communication Teacher, 24(4), 221-228. http://dx.doi.org/10.1080/17404622.2010.513036

Khawaja, N. G., White, K. M., Schweitzer, R., \& Greenslade, J. (2008). Difficulties and coping strategies of Sudanese refugees: A qualitative approach. Transcultural Psychiatry, 45(3), 489-512. http://dx.doi.org/10.1177/1363461508094678

Lally, C. G. (2001). Service/community learning and foreign language teaching methods: An application. Active Learning in Higher Education, 2(1), 53-63. http://dx.doi.org/10.1177/1469787401002001005

Lambert-Pennington, K., Reardon, K. M., \& Robinson, K. S. (2011). Revitalizing South Memphis through an interdisciplinary community-university development partnership. Michigan Journal of Community Service Learning, 17(2), 59-70.

Littlefield, H. (2006). Service learning in business communication: Real-world challenges develop real-world skills. Business Communication Quarterly, 69(3), 319-322. http://dx.doi.org/10.1177/108056990606900311

Mitton-Kükner, J., Nelson, C., \& Desrochers, C. (2010). Narrative inquiry in service learning contexts: Possibilities for learning about diversity in teacher education. Teaching and Teacher Education, 26(5), 1162-1169. http://dx.doi.org/10.1016/j.tate.2010.01.001

National ELT Accreditation Scheme. (2014). Standards and criteria for English language teaching (ELT) centres. Retrieved February 25, 2014, from http://www.neas.org.au/wp-content/uploads/2013/05/NEASStandards-2008.pdf

Petersen, N., \& Dunbar-Krige, H. (2012). Educating educational practitioners for a post-apartheid South Africa: Using service-learning to integrate school communities and university students. In T. Murphy, \& J. E. C. Tan (Eds.), Service-learning and educating in chanllenging contexts: International perspectives (pp. 71-87). New York: Continuum.

Roschelle, A. R., Turpin, J., \& Elis, R. (2000). Who learns from service learning? American Behavioral Scientist, 43(5), 839-847. http://dx.doi.org/10.1177/00027640021955630

Semlak, J. L., Pearson, J. C., Amundson, N. G., \& Kudak, A. D. H. (2008). Navigating dialectic contradictions experienced by female African refugees during cross-cultural adaptation. Journal of Intercultural Communication Research, 37(1), 43-64. http://dx.doi.org/10.1080/17475750802077396 
Smolen, L. A., Zhang, W., \& Detwiler, S. (2013). Engaged teaching and learning with adult Karen refugees in a service-learning site. TESOL Journal, 4(3), 534-554. http://dx.doi.org/10.1002/tesj.94

Sparks, R. L. (2012). Individual differences in L2 learning and long-term L1-L2 relationships. Language Learning, 62(s2), 5-27. http://dx.doi.org/10.1111/j.1467-9922.2012.00704.x

Stoller, F. L. (1999). Time for change: A hybrid curriculum for EAP programs. TESOL Journal, 8(1), 9-13. http://dx.doi.org/10.1002/j.1949-3533.1999.tb00150.x

UWS Engagemennt. (2014). Retrieved February 22, 2014, from http://www.uws.edu.au/community/engagement

Wachob, P., \& Williams, R. S. (2010). Teaching English to refugees in transition: Meeting the challenges in Cairo, Egypt. TESOL Quarterly, 44(3), 596-605. http://dx.doi.org/10.5054/tq.2010.232341

Yang, P. (2011). Developing cross-cultural communication competence through translation. In A. Arnall, \& U. Ozolins (Eds.), Proceedings of the "Synergise!" Biennial National Conference of the Australian Institute of Interpreters and Translators: AUSIT 2010 (pp. 48-65). Newcastle upon Tyne, UK: Cambridge Scholars Publishing.

Yang, P. (2012). Complimentary and derogatory wordings in English-Chinese translation. Shanghai Journal of Translators, 27(4), 28-30.

Yang, P. (2013). Two heads are better than one: Team teaching in TESOL internship. Studies About Languages, 23, 113-125. http://dx.doi.org/http://dx.doi.org/10.5755/j01.sal.0.23.4995

\section{Notes}

Note 1. AMEP is funded by the Department of Immigration and Citizenship of the Commonwealth (https://www.immi.gov.au/living-in-australia/help-with-english/amep/) and delivered by Navitas English Colleges and other service providers.

Note 2. SEE, managed by the Department of Industry of the Commonwealth (http://www.innovation.gov.au/ SKILLS/LITERACYANDNUMERACY/SEE/Pages/default.aspx), is developed out of Language, Literacy and Numeracy Program (LLNP) and was named as such between 2002 and 2012.

Note 3. Home Tutor Scheme with Mission Australia provides an individualized and personalized tutorial service to newly arrived adult migrants to help them learn the basics of the English language (http://sd.missionaustralia.com.au/106-home-tutor-scheme).

Note 4. According to a document issued by Mission Australia (https://www.missionaustralia.com.au/ how-you-can-help-page/volunteer-with-us/find-a-volunteer-role/nsw?view=docman), home tutors need to have competent level of spoken and written English, without formal qualifications or experience. Prior to giving tutoring for a minimum of ten weeks (one hour a week) in a migrant or refugee's home, they will be provided with 16-hour free tutor training courses over a period of four weeks.

\section{Copyrights}

Copyright for this article is retained by the author(s), with first publication rights granted to the journal.

This is an open-access article distributed under the terms and conditions of the Creative Commons Attribution license (http://creativecommons.org/licenses/by/3.0/). 